\title{
Rediscovery, resurrection and lectotypification of endemic Isoetes sampathkumarnii L. N. Rao from India
}

\author{
Sachin M. Patil ${ }^{1,2}$, Satish S. Patil ${ }^{3}$, Suresh K. Patel ${ }^{4} \&$ Kishore S. Rajput $^{1^{*}}$ \\ ${ }^{1}$ Department of Botany, Faculty of Science, The Maharaja Sayajirao University of Baroda, Vadodara 390 002, India \\ ${ }^{2}$ Department of Botany, Modern College of Arts, Science and Commerce, Ganeshkhind Pune 411 053, India \\ ${ }^{3}$ Department of Botany, Doodhsakhar Mahavidyalaya, Bidri 416 208, India \\ ${ }^{4}$ Department of Botany, Gujarat Arts and Science College, Ellis Bridge, Ahmedabad 380 006, India \\ *Email: ks.rajput15@gmail.com
}

\section{ARTICLE HISTORY}

Received: 22 June 2021

Accepted: 12 September 2021

Available online: 30 September 2021

Revised version: 04 October 2021

\section{KEYWORDS}

Karnataka

Jambughoda wildlife

Velum

Reticulate spores
ABSTRACT

An interesting species of Isoetes was collected from Jambughoda, Wildlife Sanctuary, Gujarat. After a review of literature and comparison of the morphological characters with type specimens, it was identified as I. sampathkumarnii L. N. Rao. It is endemic species of south India and rediscovered after a lapse of 63 years. The species shows several features that make it unique in the genus. Earlier, $I$. sampathkumarnii was also treated as synonym of $I$. coromandelina L.f. and I. sahyadrii Mahabala. However, it has an idiosyncratic velum character and spore ornamentation that makes it different from other species. Hence, the authors resurrected it as a distinct species. The original material is ambiguous hence, a lectotype of I. sampathkumarnii has been designated here.

\section{Introduction}

Isoetes is an interesting and unique pteridophyte, popularly known as 'quillworts' or 'Merlin's grass'. Available literature indicates that nearly $300-350$ species are distributed worldwide, of which 19 species, one subspecies and four varieties have been documented from India (1). Among these, only four species have been recognized viz., I. coromandelina L.f., $I$. dixitii Shende, I. sahyadrii Mahabale and $I$. udupiensis (2). All the Indian taxa are described based on velum characters, megaspore ornamentation and chromosome counts. However, several species are published by earlier researchers that are yet to be recognized $(1,2)$ and accepted as distinct species, of which the I. sampathkumarnii is one of them. The status of I. sampathkumarnii is changing from time to time because after its description as a new species, no reports were found in other parts of the state or country. Initially, it was $(3,4)$ merged under $I$. coromandelina. Later, lectotypification and epitypification of $I$. sahyadriensis Mahabale $\quad(=I$. sahayadrii) was proposed and merged all the species having reticulate spores including I. sampathkumarnii (5). Further, it was mentioned that, uncertainty about the status of I. sampathkumarnii, which is characterized by the presence of disconnected ridges on the megaspores. The lectotypification and epitypification proposed (5) were later rejected (6). The authors of the present study agree with this (6) and concluded that $I$. sampathkumarnii stands as a distinct species in the reticulate complex of Isoetes (Fig. 1).

During the survey of pteridophytes from Gujarat, an interesting specimen of Isoetes was collected in September and October 2017 for the first time and subsequently observed regularly till date. After comparing the characters, type specimens and spore characteristics, it was identified as I. sampathkumarnii L. N. Rao. Therefore, in the present communication, the authors report it as a rediscovery of $I$. sampathkumarnii and also proposed the resurrection of the species. It was found that typification of $I$. sampathkumarnii was not designated earlier. Hence, a lectotype has been designated here.

\section{Materials and Methods \\ Collection of plant materials}

Isoetes sampathkumarnii was collected from Jambughoda Wildlife Sanctuary during 2017-20. For comparative study, I. panchganiensis was collected from Panhala Fort, Kolhapur during 2018-19. 

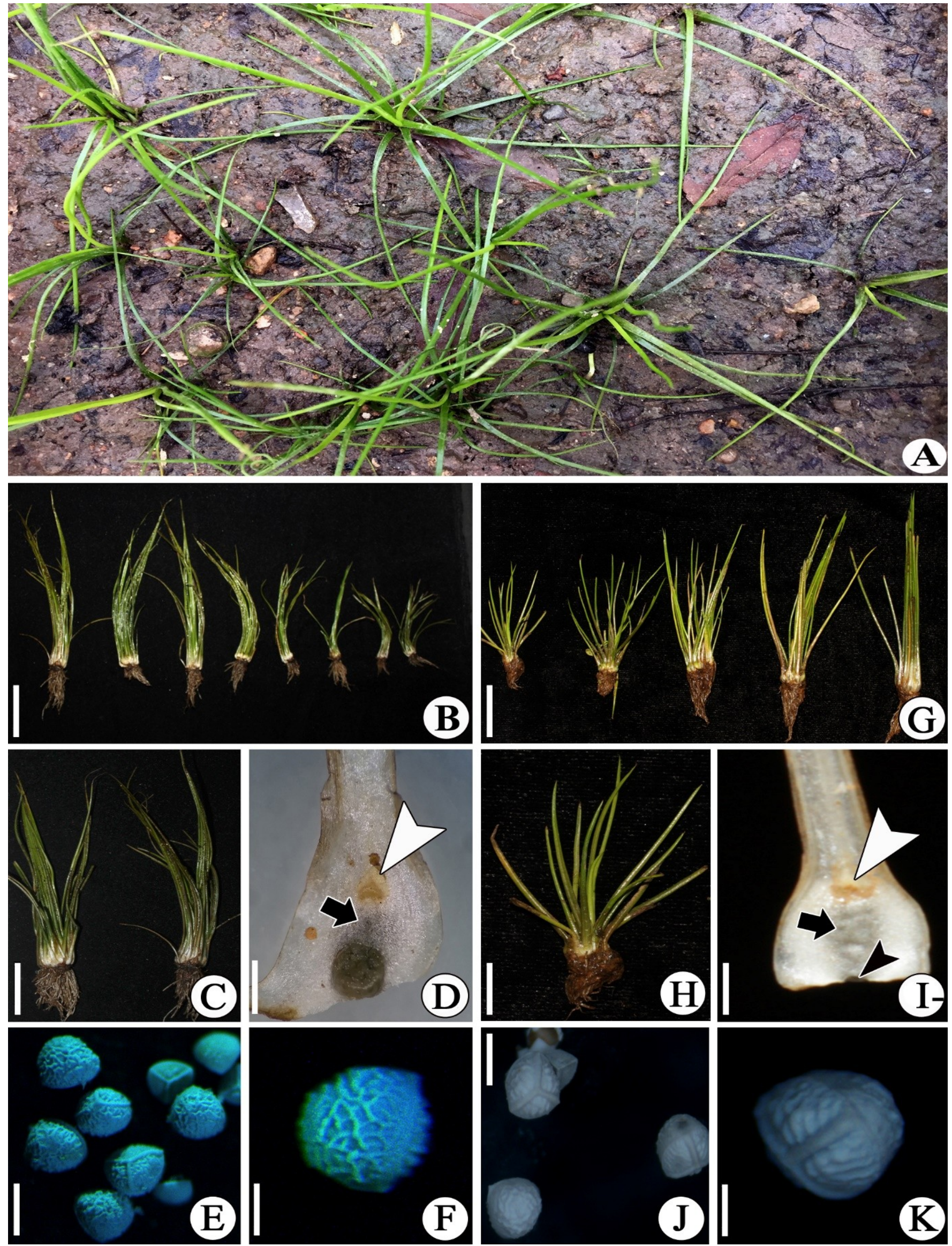

Fig. 1A. Habit of Isoetes sampathkumarnii, B. Range of variations, C. Enlarged view, D. Sporophyll showing ligule (arrowhead) and velum covering half of the sporangium (arrow), E. Spores, F. Enlarged single spore, G. Range of variations in Isoetes panchganiensis, H. Enlarge view, I. Sporophyll showing ligule (arrowhead) and velum covering the entire sporangium (black arrow). Note the slit-like opening (small, black arrowhead) at the base of the sporangium, J. Spores, $\mathbf{K}$. Enlarged single spore. Scale bar: B \& G= $3 \mathrm{~cm}, \mathbf{C} \& \mathbf{H}=5 \mathrm{~cm}, \mathbf{D} \& \mathbf{I}=5 \mathrm{~mm}, \mathbf{E} \&$ $\mathbf{J}=250 \mu \mathrm{m}, \mathbf{F} \& \mathbf{K}=200 \mu \mathrm{m}$ 


\section{Identification and Voucher specimens}

The collected specimens were identified with the help of available literature (1, 7-11). Voucher specimens are deposited at BARO, the herbarium of the Department of Botany, The Maharaja Sayajirao University of Baroda, Vadodara, Gujarat. The authors also had a personal consultation with Prof. S. P. Khullar for the confirmation of the identity of the species.

\section{Conservation status}

It was analysed by using the criteria given by IUCN (12) Red list criteria (Version 2020-2).

\section{Results and Discussion}

\section{Taxonomic account}

Isoetes sampathkumarnii L.N. Rao, Curr. Sci. 13(11): 286. 1944.

Lectotype (designated here), India, Karnataka, Bangalore, Govt. Bot. Gard., 06 August 1944, L.N.Rao, s.n. K000518076, image!; isolectotype, Bangalore, South India, Govt. Bot. Gard., L.N.Rao s.n. CAL0000063267!

Plant submerged, erect; corm two-three lobed, subterranean, covered by traces; sporophylls 5-16 per plant, 4-16 cm, dark green, base white, spirally arranged, linear, tapering towards apex, broader at the base, margin membranaceus; ligule 1.3-2.5 mm wide, and $0.8-2 \mathrm{~mm}$ present, thin, membranaceus, apex acute, margin ciliate, base cordate, triangular, yellow-brown; peripheral strands absents; air chambers presents, 4; velum present, $1 / 2$ to $3 / 4$ covering the sporangia; sporangium 5-7 × $1-3 \mathrm{~mm}$, longer than broad, dimorphic, ovate, white and at maturity it turns reddish-brown, covered with traces; megaspores 270-350 $\mu \mathrm{m}$ in diameter, trilete, reticulate, grey-black when wet, turns white after drying; microsporangia and microspores are not found.

\section{Distribution: India}

India: Karnataka and Gujarat (Jambughoda Wildlife Sanctuary).

Ecology: The species is growing along the periphery of shallow water streams and reservoirs. Specimens are collected in the late monsoon when the water level was low.

Specimens examined: Lalbagh Bot. Gard., 17/10/1958, Subramanyam 7078 (CAL); Gujarat, Shivrajpura, Jambughoda Wildlife Sanctuary, 19/09/2019, SMP \& KSR 1050 (BARO).

Conservation Status: Isoetes sampathkumarnii is rediscovered from Jambughoda Wildlife Sanctuary. This species is luxuriously growing along the periphery of wetlands, on flat surfaces along the seasonal streams. A population of about 1000 individuals were found and the Area of Occupancy (AOO) is $50 \mathrm{~km}^{2}$. However, other forest areas of the state are yet to be explored completely. Additionally, we assume that the species might be distributed in similar ecological conditions. Therefore, more floristic explorations are needed to determine and document the full range of distribution. Hence, according to
IUCN (12) criteria, at present, I. sampathkumarnii is considered data deficient (DD) species.

\section{Habitat dominance in late monsoon season}

Like all other quillwort species, I. sampathkumarnii is a submerged hydrophytic herb inhabiting the periphery of the wetlands or seasonal streams. In the early or mid-monsoon, this species could not be noticed during several excursions from 2014-2017. During our visit in 2017 at the late monsoon to Jambughoda Wildlife Sanctuary, authors recorded more than 1000 small-sized Isoetes individuals growing along the periphery of reservoirs and seasonal streams. After a detailed study and consultation at CAL, this population was identified as I. sampathkumarnii. In the early monsoon season, the periphery region of the lake, slow running small streams and open adjacent land flourish with $I$. coromandelina (having tuberculate spores), whereas in the late monsoon season a population of small individuals flourishing with $I$. sampathkumarnii (reticulate spores).

\section{The general structure of the velum and spore morphology}

Velum is a thin, membranaceus outer covering of sporangium present in some Isoetes species. It is either rudimentary (I. dixitii Shende), half to $1 / 3$ of sporangium (I. sampathkumarnii) or fully cover the sporangium with a slit opening at the base (I. panchganiensis). It is a constant character that is used to segregate the species from each other. The species in which velum is absent, such species are having tuberculate spores (except $I$. dixitii and $I$. sahyadrii Mahabale) whereas the species in which velum is present such species having reticulate spores (except $I$. rajasthanensis). Therefore, the majority of Indian species are identified based on the presence or absence of velum, tuberculate or reticulate spores and chromosome numbers (1). The sporangium of $I$. sampathkumarnii is covered by half to $1 / 3$ velum and encloses reticulate spores (Fig. 1).

\section{Rediscovery and resurrection of Isoetes sampathkumarnii}

When working on Ophioglossum from Jambughoda Wildlife Sanctuary, the authors came across smallsized Isoetes in the late monsoon. During the early monsoon, authors collected $I$. coromandelina, from the same location which was $35-50 \mathrm{~cm}$ in height, without velum covering on the sporangium and having tuberculate spores. However, the species which was collected in the late monsoon was less than $15 \mathrm{~cm}$, and sporangium was covered with half to $1 / 3$ velum. Further, by comparing other morphological characters with the type description and spore, it was identified as endemic species I. sampathkumarnii that was described by Rao (4) from Lalbagh Garden, Bangalore. After the discovery, a single collection was made by Subramanyam in 1958. Since then, it was not collected from the type locality and any other places from India. Thus, after the lapse of 63 years, the species was rediscovered. This species was merged under Isoetes coromandelina and I. sahyadrii, however, both the species are having tuberculate spore ornamentation whereas $I$. sampathkumarnii is having reticulate 
spores. Therefore, it stands as distinct species in the reticulate complex and thus, at present authors resurrected the species.

\section{Lectotyfication}

Rao (8) mentioned that the type specimens deposited at $\mathrm{K}, \mathrm{CAL}$ and in the Central College, University of Mysore, Bangalore. It seems to be of the same gathering deposited in three different herbaria. So, they are to be treated as syntypes (13). The citation of a type before 1990 cannot be considered that of a holotype unless one particular herbarium was indicated in the protologue (and only one specimen of the gathering was deposited there) or if it were made clear that only a single specimen of the gathering existed, or if there is evidence that only one particular specimen was used. More commonly there will be duplicates, often housed in more than one institution, and these must all be treated as syntypes (Art. 40 Note 1). Marsden, C.R. on 20/04/1977 annotated the Kew specimen as the lectotype but it was not formally published. Hence, the Kew specimen (K000518076) has been designated here as the lectotype.

\section{Comparative study}

The comparative account of Isoetes coromandelina, I. panchganiensis, I. sahyadrii and $I$. sampathkumarnii is provided herewith in Table 1. In the available recent literature, $I$. sampathkumarnii was misidentified and merged under the species $I$. coromandelina (6). Later, it was merged under the species $I$. sahyadrii $(2,8)$. However, both the species, Isoetes coromandelina and I. sahyadrii are having tuberculate spore ornamentation whereas reticulate spore ornamentation was observed in I. sampathkumarnii. Therefore, I. sampathkumarnii stood as distinct species and was resurrected here. Due to the presence of velum and reticulate spores, the present specimen was also compared with $I$. panchganiensis. This comparison showed that in I. panchganiensis the velum completely covered the sporangia with slit at the base and possess reticulate spores whereas in I. sampathkumarnii the velum covers half to one-third of sporangia that enclose reticulate spores (Table 1). Therefore, both species showed morphological differences and stand as distinct species.

\section{Conclusion}

The present study concludes the rediscovery of I. sampathkumarnii from a new locality and has resurrected the species. A lectotype has been designated here. This study also suggests that at present there are two confirmed species of Isoetes in the reticulate complex i.e., I. sampatkumarnii and I. panchganiensis. Further, studies are warranted to fully understand the reticulate complex by reexamining the morphological characters, their growing season, elevation, cytological and molecular studies.

\section{Acknowledgements}

Authors are grateful to the Science and Engineering Research Board (SERB) for financial support under the National Post-Doctoral Fellowship (NPDF) programme. The authors would like to thank Prof. S. P. Khullar for the confirmation of the identity and suggestions. We are also thankful to Dr Devendra Singh, Scientist C, Central National Herbarium, Howrah, for his help in facilitating our study of herbarium specimens. The authors also express their gratitude towards Dr. K. N. Gandhi and the anonymous reviewers for their valuable nomenclature suggestions and on the earlier version of the manuscript respectively.

\section{Authors' contributions}

SMP collected the plant material, identification, photography of Isoetes sampathkumarnii and a preliminary draft of the manuscript was written;

SKP helped during the collection plant material, processing of the plant material and preliminary draft writing; SSP collected Isoetes panchganiensis and its microphotography;

KSR provided administrative support, laboratory facilities, arrange field visit, preparation of figures and overall compilation of the manuscript.

Table 1. Comparative account of some Isoetes species

\begin{tabular}{|c|c|c|c|c|}
\hline $\begin{array}{l}\text { Attributes/ } \\
\text { Name of Species }\end{array}$ & I. coromandelina & I. panchganiensis & $\begin{array}{l}\text { I. sahyadrii } \\
\text { (I. sahyadriensis) }\end{array}$ & I. sampathkumarnii \\
\hline Type Locality & $\begin{array}{l}\text { Coromandel coast, } \\
\text { Tamil Nadu }\end{array}$ & $\begin{array}{l}\text { Panchgani, } \\
\text { Maharashtra }\end{array}$ & $\begin{array}{l}\text { Panchgani } \\
\text { Maharashtra }\end{array}$ & $\begin{array}{l}\text { Bangalore, } \\
\text { Karnataka }\end{array}$ \\
\hline Rhizomorph & $\begin{array}{l}\text { Tri-lobed } \\
\text { (rarely tetra or penta lobed) }\end{array}$ & Tri-lobed & Tri-lobed & Bi-lobed \\
\hline Sporophylls per plant & $\begin{array}{l}17-9 \text { (in triploid) } \\
8-23 \text { (in tetraploid) }\end{array}$ & $9-20$ & $4-32$ & $3-16$ \\
\hline Peripheral strands & $\begin{array}{l}\text { 4-main, several subsidiary } \\
\text { strands }\end{array}$ & Absent & Absent & Absent \\
\hline Velum & Absent & $\begin{array}{l}\text { Completely covered for } \\
\text { the sporangia except for a } \\
\text { base arched slit }\end{array}$ & $\begin{array}{l}\text { Completely covered the } \\
\text { sporangia except for a base } \\
\text { arched slit }\end{array}$ & $\begin{array}{l}1 / 2 \text { to } 3 / 4 \text { covered the } \\
\text { sporangia }\end{array}$ \\
\hline Ligule & Triangular-cordate & Triangular & Triangular with armed & Triangular \\
\hline Megaspores & $\begin{array}{l}\text { Tuberculate, } \\
\text { tubercles even }\end{array}$ & Reticulate & Tuberculate & Reticulate \\
\hline
\end{tabular}




\section{Compliance with ethical standards}

Conflict of interest: No research conflicts.

\section{Ethical issues: None.}

\section{References}

1. Patil SM, Rajput KS. The genus Isoetes from India: An overview Plant Sci Today. 2017;4(4):213-26. https://doi.org/10.14719/ pst.2017.4.4.339

2. Fraser-Jenkins CR, Gandhi KN, Kholia BS, Benniamin A. An Annotated Checklist of Indian Pteridophytes Part-1 (Lycopodiaceae to Thelypteridaceae). Messrs Bishen Singh Mahendra Pal Singh; 2017;p. 54-60.

3. Fraser-Jenkins CR. New Species Syndrome in Indian Pteridology and the ferns of Nepal. International Book Distributors, Dehra Dun; 1997; p. 404.

4. Fraser-Jenkins CR. Taxonomic Revision of Three Hundred Indian Subcontinental Pteridophytes with a Revised Census-List. Bishen Singh Mahendra Pal Singh, Dehra Dun. 2008; p. 685.

5. Fraser-Jenkins CR. Lectotypification and epitypification of Isoetes sahyadriensis (Isoetaceae) from S. W. India. Indian J. Forestry. 2015;38(3):231-32.

6. Mazumdar J, Rajput KS, Patil SM. (2565) Proposal to reject the name Isoetes sahyadrii (Isoetaceae). Taxon. 2017;66 (6):1470.

7. Mahabale TS. On a new species of Isoetes in India. Curr Sci 1938;7:62-63.

8. Rao LN. A new species of Isoetes from Bangalore Mysore State. Curr Sci. 1944;13: 286-87.
9. Pant DD, Srivastav GK. The genus Isoetes in India. Proc Natl Inst Sci India, Pt B Biol Sci. 1962;28:242-80.

10. Gena CB, Bharadwaja TN. Three new species of genus Isoetes L. from Rajasthan. Jour Bomb Nat Hist Soc. 1984;81:165-68.

11. Srivastava GK, Pant DD, Shukla PK. The genus Isoetes in India Amer Fern J. 1993;83(4):105-19. https://doi.org/10.2307/1547587

12. IUCN. The IUCN Red List of Threatened Species. 2020. Version 2020-2. Available from: https://www.iucnredlist.org. Downloaded on 09 July 2020.

13. McNeill J. Holotype specimens and type citations: General is sues. Taxon. 2014;63:1112-13. http://dx.doi.org/10.12705/635.7

\section{Additional information}

Peer review information: Plant Science Today thanks Sectional Editor and the other anonymous reviewers for their contribution to the peer review of this work.

Reprints and permissions information is available at https://horizonepublishing.com/journals/index.php/PST/open_access_policy

Publisher's Note: Horizon e-Publishing Group remains neutral with regard to jurisdictional claims in published maps and institutional affiliations.

To cite this article: Patil SM, Patil SS, Patel SK, Rajput KS. Rediscovery, resurrection and lectotypification of endemic Isoetes sampathkumarnii L. N. Rao from India. Plant Science Today. 2021;8(4):900-904. https://doi.org/10.14719/ pst.2021.8.4.1343

Plant Science Today, published by Horizon e-Publishing Group, is covered by Scopus, Web of Science, BIOSIS Previews, Clarivate Analytics, etc. See https://horizonepublishing.com/journals/index.php/PST/indexing_abstracting 